\title{
Genetic Variation in an International Provenance-Progeny Test of Pinus caribaea Mor. var. bahamensis Bar. et Gol., in São Paulo, Brazil
}

\author{
By A. M. Sebbenn ${ }^{1,2)}$, F. C. Arantes ${ }^{3)}$, O.V. Boas ${ }^{1)}$ and M. L. M. Freitas ${ }^{1)}$
}

(Received $5^{\text {th }}$ December 2006)

\begin{abstract}
A combined provenance-progeny test of Pinus caribaea var. bahamensis was established in Paraguaçu Paulista Experimental Station, São Paulo State, Brazil, in a "compact family" blocks design with 14 provenances, 2 to 10 families per provenance, 5 individuals per subplot, and 7 replications. Variation among and within island, provenances and families and genetic parameters for d.b.h., height, and real volume were investigated, about 15 years after planting. Analysis of variation for all studied traits revealed significant differences among islands, provenances within island and families within islands, suggesting the possibility of increasing the timber yield through selection of the more productive provenances and families within the best island. Genetic correlations on growth traits were high and statistically significant, indicating that substantial gains could be made through indirect selection for one trait based on direct selection for another. Norman Castle provenance from Abaco Island performed best for d.b.h. height and volume, while San Andros and Little Harbour Cay, both from Andros Island performed worst for d.b.h. and height, respectively, and South Riding from Grand Bahamas Island performed worst for volume. The best provenance growth compared to that $P$. elliottii var. elliottii species at the same experimental site suggests that $P$. caribaea var. bahamensis has high silvicultural potential for the Paraguaçu Paulista region.
\end{abstract}

Key words: Pinus caribaea, provenance-progeny test, genetic variation, genetic parameters, quantitative traits.

\section{Introduction}

The introduction of exotic tree species in Brazil has provided substantial benefits to socioeconomic development for diverse regions, in special where the climate and soil characteristics are not adequate for agricultures activities (Missio et al., 2004). Among the exotic tree species, the fast growing Pinus sp. has a great success for timber, pulp and resin yield. In Brazil, Pinus sp. intensive commercial reforestations started in 1950. The first intensive plantings were established by São Paulo Forest Service (actual São Paulo Forest Institute). After this first step, private companies start reforestation using Pinus sp., especially for pulp production.

Tropical Pinus species are intensively planted in São Paulo state due it fast growth, and good adaptation to soil and climate. Among the diverse tropical Pinus species, Pinus caribaea Mor. var. bahamensis Bar. et

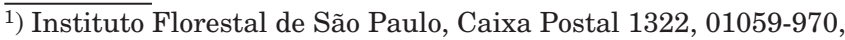
São Paulo.

2) Corresponding author: Present address: Instituto Florestal de São Paulo, Caixa Postal 1322, 01059-970, São Paulo. E-mail: alexandre.sebbenn@pq.cnpq.br

3) UNESP, AV. Brasil Centro, 56, 15385-000, Ilha Solteira, SP.
Gol., has prominence due it fast growth, good adaptations, high timber and resin yield. This species is originated from the Bahamas Islands, in two areas distant $600 \mathrm{~km}$ a part (BARRETT and GOLFARI, 1962). The first area include Grand Bahamas, Great Ábaco, Andros and New Providence islands, between North latitude $23^{\circ}$ to $27^{\circ}$. The second area includes Caicos Island between North Latitude $21^{\circ}$ to $22^{\circ}$. In these island the species is found in altitudes ranging from sea level to $30 \mathrm{~m}$, in tropical clime $\left(25^{\circ} \mathrm{C}\right)$, sub-humid (average annual precipitation range from 700 to $1.300 \mathrm{~mm}$ ), with dryer period of six months, and in alkaline soils ( $\mathrm{pH} 7.5$ to 8.5). The growth is between $P$. caribaea Mor. var. caribaea Bar. et Gol. and Pinus elliottii Eng. var. elliottii (BARRETT and GOLFARI, 1962). This monoecious wind-pollinated species have a mixed mating system (MATHESON et al., 1989; ZHENG and ENNos, 1997) and significant levels of inbreeding have been detected in some populations, as San Andros $(F=0.218)$, Adelaide $(F=0.180)$ and High Rock $(F=0.139$, ZHeng and EnNos, 1999).

Significant genetic variation for grown, stem form and resin production traits have been detected among P. caribaea var. bahamensis provenances and families, suggesting the species have high silvicultural potential for tree breeding (SEBbENn et al., 1994; ZHENG et al., 1994; Gurgel GarRido et al., 1996, 1999; Missio et al., 2004). Estimates of heritability coefficients in progeny test have shown substantial genetic control for grown, stem form and resin production and genetic gains have been estimated at $23.4 \%$ for height, $30.6 \%$ for d.b.h. (ZHENG et al., 1994), 8.3\% for real volume (SEBBENN et al., 1994), and $46.2 \%$ for resin production (GURGEL GARRIDO et al., 1999). These results showing the high potential of the species for improved the stem form and increase in timber and resin yield through selection of the more productive provenances and families.

The goal of this study was investigated the genetic variation for growth traits in 97 families from 14 $P$. caribaea var. bahamensis provenances originated from four Bahamas islands in Paraguaçu Paulista region, São Paulo state, Brazil. Our objectives were: $i$ ) study the genetic variation in P. caribaea var. bahamensis provenances for the main silvicultural traits in the region of Paraguaçu Paulista - SP; ii) study the correlation between grown traits; iii) classify provenances according to their silvicultural performance.

\section{Material and Methods}

\section{Sampling, experimental site and design}

The open-pollination seeds for this trial were collected from parent trees in $14 P$. caribaea var. bahamensis 
Table 1. - P. caribaea var. bahamensis provenances details and number of family sampled per provenance.

\begin{tabular}{|c|c|c|c|c|}
\hline Island/Provenances & Families & $\begin{array}{c}\text { Latifude } \\
(\mathrm{N})\end{array}$ & $\begin{array}{c}\text { Longitude } \\
\text { ( W) }\end{array}$ & $\begin{array}{c}\text { Altifude } \\
\text { (m) }\end{array}$ \\
\hline \multicolumn{5}{|l|}{ Abaco } \\
\hline Codar Harbour 65 & 10 & $26^{\circ} 53^{+}$ & $77^{\circ} 39^{\prime}$ & 10 \\
\hline Norman Castle 66 & 8 & $26^{\circ} 45^{\prime}$ & $77^{\circ} 26^{\prime}$ & 5 \\
\hline Central Abaco 67 & 3 & $26^{\circ} 26^{\prime}$ & $77^{\circ} 06^{\prime}$ & 5 \\
\hline Sandy Point 68 & 10 & $26^{\circ} 02^{\prime}$ & $77^{\circ} 12^{\prime}$ & 10 \\
\hline \multicolumn{5}{|l|}{ Andros } \\
\hline San Andros 69 & 7 & $24^{\circ} 57^{\prime}$ & $78^{\circ} 01^{1}$ & 10 \\
\hline Staniard Crock 70 & 10 & $24^{\circ} 50^{\circ}$ & $77^{\circ} 55^{\prime}$ & 10 \\
\hline Roker Cay 71 & 5 & $24^{\circ} 07^{*}$ & $77^{\circ} 44^{\prime}$ & 8 \\
\hline Kemps Bay 72 & 7 & $24^{\circ} 06^{*}$ & $77^{\circ} 36^{\prime}$ & 9 \\
\hline \multicolumn{5}{|l|}{ Grand Bahama } \\
\hline Frocport 73 & 2 & $26^{\circ} 32^{+}$ & $78^{\circ} 45^{\prime}$ & 5 \\
\hline South Riding 74 & 7 & $26^{\circ} 40^{+}$ & $78^{\circ} 13^{\prime}$ & 10 \\
\hline Maclcan s Town Cay 75 & 4 & $26^{\circ} 34^{\prime}$ & $77^{\circ} 55^{\prime}$ & 2 \\
\hline Little Harbour Cay 76 & 8 & $26^{\circ} 33^{\prime}$ & $77^{\circ} 53^{\prime}$ & 2 \\
\hline \multicolumn{5}{|l|}{ New Providence } \\
\hline Adelaide 77 & 7 & $25^{\circ} 00^{\circ}$ & $77^{\circ} 26^{\prime}$ & 10 \\
\hline East New Providence 78 & 9 & $25^{\circ} 01^{+}$ & $77^{\circ} 24^{\prime}$ & 5 \\
\hline
\end{tabular}

provenances across four Caribean Islands in Central America (Table 1) by the Oxford Forestry Institute, United Kingdom. A total of 97 families were sampled, with the number of families per provenance ranging from 2 to 10 (Table 1). The provenance and progeny test was established in 1990 at the Paraguaçu Paulista Experimental Station in São Paulo State, Brazil (Latitude $22^{\circ} 25^{\prime} \mathrm{S}$, Longitude $50^{\circ} 35^{\prime} \mathrm{W}$ and $490 \mathrm{~m}$ above sea level). At the station the mean annual rainfall is 1131.1 mm with maximum average month temperature of $22^{\circ} \mathrm{C}$ and minimum of $10^{\circ} \mathrm{C}$. The soil of experimental trial is a red dark latosol. The winter is dry (from June to September). The trial was established as a Randomized Compact-family Block design (WRIGHT, 1978), with 14 provenances (main plots), 2 to 10 families per provenance (subplots), 5 individuals per subplot and 7 replicates. Initial spacing was $3 \mathrm{~m}$ by $3 \mathrm{~m}$. Three external border rows were used. In 1996 (six years after planting), the trials was thinned, removing the worst two trees for resin yield within a subplot. Since resin production is not correlated with growth traits (GURGEL GARRIDO and KAGEYAMA, 1993; ROMANELLI and SEBBENN, 2004), it is expected that the within plot thinning did not affected the genetic variability for the other traits.

For the present study, the trial was assessed at 15 years after planting for diameter at breast height (d.b.h.) and total tree height (h). From d.b.h. and height, the real volume was calculated using the expression: $V_{r}=\left[\pi(d . b . h .)^{2} h F_{F}\right] / 4$, where $F_{F}$ is the form factor developed for species in Brazil, $F_{F}=0.47$ (SEBBENN et al., 1994). Additionally, for growth comparisons, we established a small plot of 50 trees in a commercial stand of 16 years old of the same species and in 19 years old $P$. elliottii var. elliottii, in the same experimental station.

\section{Significance of effects}

To test the significance of effects for island, provenances within islands, and families within island an $F$ test was carry out, based on the GLM procedure of the statistical program SAS (SAS, 1989).

However, given the reduced number of families per provenance, provenances were aggregated by Islands. The linear mixed model used to estimate the components of variance was:

$$
\gamma_{i k i}=\mu+b_{i}+p_{i}+(p b)_{j i}+f_{i: k}+(j b)_{j: k i}+e_{j, k i,} \text {. }
$$

where: $Y_{i j k l}$ is the phenotypic value of the $l$ th individual of the $k$ th family from the $j$ th island in the $i$ th replication; $\mu$ is the fixed term overall mean; $b_{i}$ is the fixed effect of the $i$ th replication; $p_{j}$ is the fixed effect of the $j$ th island; $(p b)_{j i}$ is the random effect of the interaction between the $j$ th island and the $i$ th replicate; $f_{j: k}$ is the random effect of the $k$ th family in the $j$ th island; $(f b)_{j: k i}$ is the random effect of the interaction between the $k$ th 
family of the $j$ th island and the $i$ th replicate; $e_{i j k l}$ is the effect of the $l$ th tree within the $k$ th family of the $j$ th island in the $i$ th replication. The latter component includes the error effects; $i=1, \ldots, \mathrm{b}$ (b is the number of replications); $j=1, \ldots, \mathrm{p}$ ( $\mathrm{p}$ is the number of island); $k=1, \ldots, \mathrm{f}$ ( $\mathrm{f}$ is the number of families within island); $l=1, \ldots, \mathrm{n}$ ( $\mathrm{n}$ is the number of trees per family). VARCOMP procedures from SAS statistical program (SAS, 1989) was used in combination. Since the experiment was unbalanced due to unequal number of surviving trees, selection in the subplots level for resin yield in 1996, and unequal number of families per provenance, a Restricted Maximum Likelihood (REML) method was used to estimate the variance components.

The REML variance components were used to estimate the relative importance of island $\left(Q_{i}\right)$ and genetic family within island variation $\left(Q_{f(i)}\right)$ calculated as:

$$
\begin{aligned}
& \hat{Q}_{i}=\hat{\phi}_{i} /\left(\hat{\sigma}_{n}^{2}+\hat{\sigma}_{i}^{2}+\hat{\sigma}_{j}^{2}+\hat{\phi}_{i}\right) \text {. } \\
& \hat{Q}_{f(i)}=\hat{\sigma}_{i}^{2} /\left(\hat{\sigma}_{\mathrm{w}}^{2}+\hat{\sigma}^{2}+\hat{\sigma}_{f}^{2}\right) .
\end{aligned}
$$

Where $\phi_{i}$ is the GLM component of variance for island effect; $\sigma_{p r}^{2}$ is the REML variance of the interaction of island by replicate; $\sigma_{f}^{2}$ the variance of family within island effect; $\sigma_{e}^{2}$ the variance of the interaction of family within island by replicate and $\sigma_{w}^{2}$ is the variance of individual within family effect.

\section{Genetic parameter estimate}

The genetic and phenotypic variation, heritability and genetic correlations were calculated according to NAMKOONG (1979) and FALCONER and MACKAY (1996). Progeny was assumed to include half-sibs, full-sibs and self-sibs and additive genetic variance $\left(\sigma_{A}^{2}\right)$ was estimated as $\sigma_{A}^{2}=\sigma_{f}^{2} / r_{x y}$, where $\sigma_{f}^{2}$ is the genetic variance among families within provenances, and $r_{x y}$ is the relatedness coefficient within families. The relatedness coefficient within families was estimated following RITLAND (1989) as,

$$
r_{s i}=0.25(1+F)\left\lfloor 4 s+\left(t^{2}+t s r_{s}\right)\left(1+r_{s}\right)\right\rfloor,
$$

were, $F$ is the inbreeding coefficient in parental generation, $s$ is the selfing rate, $t$ is the outcrossing rate, $r_{s}$ is the selfing correlation (measure the variation in outcrossing rate among individual trees), and $r_{p}$ is the paternity correlation (measured the proportion of fullsibs within families). The outcrossing rate $(t)$ was inferred from MATHERSON et al. (1989) that estimated this parameter for two populations of the species as 0.85 and 0.93 . The used outcrossing value was the average between these two populations, 0.89 . The coefficients $F$ and $r_{s}$ were assumed to be zero and the proportion of full-sibs within families $\left(r_{p}\right)$ was assumed to be $15 \%$. Thus the estimated relatedness coefficient within families was 0.338 .

Narrow sense individual $\left(h_{i}^{2}\right)$, family $\left(h_{f}^{2}\right)$ and within family $\left(h_{w}^{2}\right)$ heritability coefficients were estimated by:

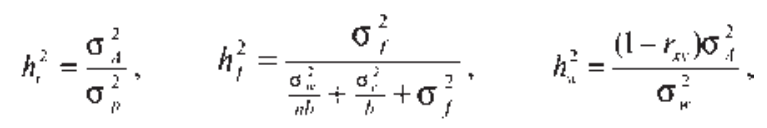

where, $\sigma_{p}^{2}$ is the total phenotypic variance estimated by $\sigma_{p}^{2}=\sigma_{w}^{2}+\sigma_{e}^{2}+\sigma_{f}^{2}$.

Genetic correlations among traits $\left(r_{g_{x y}}\right)$ were estimated according to the equations:

$$
r_{s_{1}}=\frac{\sigma_{f_{1} f_{r}}}{\sqrt{\sigma_{f_{4}}^{2} \sigma_{f_{r}}^{2}}}
$$

where, $\sigma_{f x f y}$ is the genotypic products of $x$ and $y$ traits; $\sigma_{f x}^{2}$ and $\sigma_{f y}^{2}$ are the genetic variances among families within provenances of $x$ and $y$ traits, respectively.

\section{Results and Discussion}

\section{Significance of effects}

The GLM analysis revealed significant differences among island, provenances within island and families within island for all the traits (Table 2), indicating the possibility to increase the timber yield through selection of the more productive island, provenances within island and families within island. Significant differences among the same $P$. caribaea var. bahamensis provenances were also reported in previous analysis of this trial at 2 and 6 years after planting (GURGEL GARRIDO et al., 1999), and in a repetition this trial in the Guangxi Province, China, evaluated at 2.5 years after planting (ZHeng et al., 1994). These results confirm the high genetic variation and potential of the species for tree breeding programs.

\begin{tabular}{|c|c|c|c|c|}
\hline \multirow[t]{2}{*}{ Source of variation } & \multirow[t]{2}{*}{ d.f. } & \multicolumn{3}{|c|}{ Mcan squares } \\
\hline & & d.b.h. $(\mathrm{cm})$ & Height (m) & Volume $\left(\mathrm{m}^{\mathrm{s}} /\right.$ tree $)$ \\
\hline Blocks & 6 & $63.0694 *$ & $69.3819 * *$ & $0.1199: F$ \\
\hline lsiland & 3 & $61.0318^{*}$ & $43.4503 * *$ & $0.0896 *$ \\
\hline Provenances/]sland & 10 & $37.5773 *$ & $12.3758 * *$ & $0.0422 * *$ \\
\hline Families/Island & 93 & $39.8925 *$ & $5.1274 * *$ & $0,0367 * *$ \\
\hline Error & 1753 & 16.3555 & 2.5181 & 0.0156 \\
\hline
\end{tabular}

The components of variance for island and families within island and their relative contributions toward

Table 2. - GLM mean square estimates for 15 year-old-traits provenance-progeny test of P. caribaea var. bahamensis in Paraguaçu Paulista, Brazil.

$*: \mathrm{P} \leq 0.05 ; * *: \mathrm{P} \leq 0.01$. 
Table 3. - Components of variance, importance of island $\left(Q_{i}\right)$ and family/island effects $\left(Q_{f(i)}\right)$ to total variance, and genetic parameters in provenance-progeny test of $P$. caribaea var. bahamensis in Paraguaçu Paulista, Brazil.

\begin{tabular}{|c|c|c|c|}
\hline Parameter & $\begin{array}{l}\text { d.b.h. } \\
\text { (cm) }\end{array}$ & $\begin{array}{l}\text { I Ieight } \\
\text { (m) }\end{array}$ & $\begin{array}{l}\text { Volume } \\
\left(m^{3} / \text { trec) }\right.\end{array}$ \\
\hline \multicolumn{4}{|l|}{ Components of variance } \\
\hline Variance anoug island $-\varphi_{I}^{2}$ & 0.0639 & 0.0907 & 0.00014 \\
\hline Variance annong families/Lsland $-\sigma_{t}^{2}$ & 1.1173 & 0.0674 & 0.00099 \\
\hline Phenotypic varianec within family $-\sigma_{n}^{2}$ & {$[5,4646$} & 1.7021 & 0,01450 \\
\hline Impontance of island effects $-Q$ & 0.004 & 0.049 & 0.009 \\
\hline Importance of farnily effects $-Q_{i(t)}$ & 0.063 & 0.025 & 0.059 \\
\hline \multicolumn{4}{|l|}{ Genetic parameters } \\
\hline Coefficient of genetic variation $-\mathrm{CV}_{a}$ & 4.65 & 1.68 & 10.13 \\
\hline Nawow sense individual heritability $-h_{i}^{2}$ & 0.1877 & 0.0740 & 0.1744 \\
\hline Family heritability $-h^{2}$ & 0.5583 & 0.2402 & 0.5310 \\
\hline Within family heritability - $h_{t s}^{2}$ & 0.1416 & 0.0775 & 0.1335 \\
\hline
\end{tabular}

total variance were computed (Table 3). Island effects accounted for $4.9 \%$ (height) and families within island accounted for $6.3 \%$ (d.b.h.) of total variance, suggesting that more genetic gains can be explored for height by selection of the best island and for d.b.h. by selection of the best families. The genetic differentiation among families also drops between six to 15 years of age for height whereas it increased for d.b.h. (Figure 1). The possible explanation for this pattern of genetic variation with age is that the d.b.h is more sensible to competition than height, and the selection for resin yield within subplots reduced the competition among neighbourhood tree, favouring the genetic expression of this trait. ZHENG et al. (1994) observed 15.2 and $13.6 \%$ of variation among families within provenances for d.b.h. and height, respectively, for the same provenances at 2.5 years after planting.

\section{Provenance performance}

The Freeport provenance showed the best growth for d.b.h. and volume and was the forth for height (Table 4). However, this provenance was poorly represented by number of families. Only two families were sampled and one showed very fast grown for d.b.h. and the other, medium grown. Thus, this average is probably overestimated and recommendation of this provenance needs to be taking with caution. Considering provenances with at least seven families, the best provenance for all traits was Norman Castle from Abaco Island. The second best provenance for d.b.h. and volume was Cedar Harbour

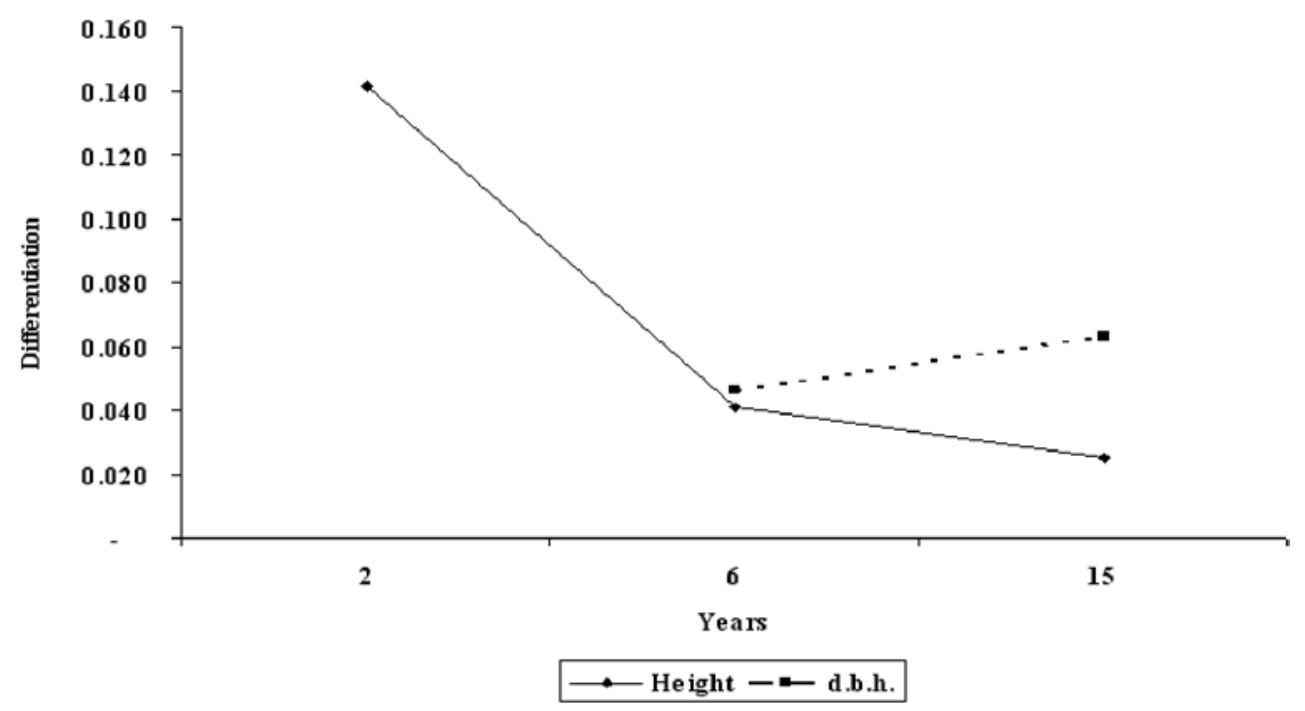

Figure 1. - Importance of family effects (as \% of total variance) for height and d.b.h. at different ages for P. caribaea var. bahamensis, in Paraguaçu Paulista-SP, Brazil. 
Table 4. - Growth data (mean \pm standard error) for each provenance at age 15 after planting in provenance-progeny test of $P$. caribaea var. bahamensis in Paraguaçu Paulista, Brazil and number of selected families. (The number in parentheses is ranks).

\begin{tabular}{|c|c|c|c|}
\hline Region/Provenance & $\begin{array}{l}\text { d.b.h. } \\
\text { (cm) }\end{array}$ & $\begin{array}{l}\text { Height } \\
\text { (m) }\end{array}$ & $\begin{array}{l}\text { Volume } \\
\left(\mathrm{m}^{3} / \mathrm{tree}\right)\end{array}$ \\
\hline \multicolumn{4}{|l|}{ Abaco } \\
\hline Codar Harbour & $23.28 \pm 0.29(3)$ & $15.62 \pm 0.10(7)$ & $0.3269 \pm 0.0097(3)$ \\
\hline Norman Castlc & $23.29 \pm 0.32(2)$ & $16.12 \pm 0.11(1)$ & $0.3374 \pm 0.0101(2)$ \\
\hline Central Abaco & $22.84 \pm 0.5](8)$ & $15.05 \pm 0.19(10)$ & $0.3000 \pm 0.0138(9)$ \\
\hline Sandy Point & $22.85 \pm 0.27(7)$ & $15.82 \pm 0.13(2)$ & $0.3169 \pm 0.0087(6)$ \\
\hline Mean & $23.06 \pm 0.13$ & $15.65 \pm 0.23$ & $0.3203 \pm 0.0080$ \\
\hline \multicolumn{4}{|l|}{ Andros } \\
\hline San Andros & $21.77 \pm 0.32(14)$ & $15.29 \pm 0.12(8)$ & $0.2818 \pm 0.0093(12)$ \\
\hline Staniard Croek & $22.72 \pm 0.34(9)$ & $15.66 \pm 0.12(6)$ & $0.3141 \pm 0.0106(8)$ \\
\hline Roker Cay & $22.67 \pm 0.50(10)$ & $14.57 \pm 0.19(14)$ & $0.2959 \pm 0.0149(10)$ \\
\hline Kcmps Bay & $23.18 \pm 0.43(4)$ & $15.26 \pm 0.15(9)$ & $0.3222 \pm 0.0135(4)$ \\
\hline Mean & $22.58 \pm 0.30$ & $15.20 \pm 0.23$ & $0.3035 \pm 0.0091$ \\
\hline \multicolumn{4}{|l|}{ Grand Bahama } \\
\hline Freeport & $24.44 \pm 0.73(1)$ & $15.66 \pm 0.32(4)$ & $0.3669 \pm 0.0280(1)$ \\
\hline South Riding & $21.85 \pm 0.35(13)$ & $15.04 \pm 0.13(11)$ & $0.2770 \pm 0.0097(14)$ \\
\hline Maclcan's Town Cay & $22.12 \pm 0.47(11)$ & $14.97 \pm 0.19(12)$ & $0.2862 \pm 0.0142(11)$ \\
\hline Little Harbour Cay & $21.90 \pm 0.35(12)$ & $14.87 \pm 0.14(13)$ & $0.2775 \pm 0.0097(13)$ \\
\hline Mean & $22.58 \pm 0.62$ & $15.13=0.18$ & $0.3019 \pm 0.0218$ \\
\hline \multicolumn{4}{|l|}{ New Providence } \\
\hline Adelaide & $22.91 \pm 0.35(6)$ & $15.66 \pm 0.20(5)$ & $0.3166 \pm 0.0109(7)$ \\
\hline Kast Nicw Providence & $22.97 \pm 0.30(5)$ & $15.70 \pm 0.14(3)$ & $0.3210 \pm 0.0094(5)$ \\
\hline Mean & $22.94 \pm 0.03$ & $15.68=0.02$ & $0.3188 \pm 0.0022$ \\
\hline General mean $(\bar{x})$ & $22.73 \pm 0.19(1.52)^{\mathrm{a}}$ & $15.46 \pm 0.12(1.03)$ & $0.3100 \pm 0.0068(0.0207)$ \\
\hline \multicolumn{4}{|l|}{ Commercial stands } \\
\hline P. c. var. bahamensis (16 year) & $23.64 \pm 0.91(1.48)$ & $18.33 \pm 0.40(1.15)$ & $0.4190 \pm 0.0376(0.0260)$ \\
\hline P. ellionii var elliothi (19 ycar) & $25.44 \pm 0.83(1.34)$ & $16.26 \pm 0.29(0.85)$ & $0.4420 \pm 0.0329(0.0230)$ \\
\hline
\end{tabular}

a: annual mean growth.

and for height was Saint Point, both also from Abaco Island. San Andros performed worst for d.b.h., Little Harbour Cay performed worst for height, and South Riding performed worst for volume. Norman Castle and Cedar Harbour provenances were also appointed as of the best for d.b.h. and height at 2 and 6 years old by Gurgel GarRIDO et al. (1999). Interestingly, Norman Castle was the best provenance for d.b.h., the second for crown width, and the third for height and Cedar Harbour was the best for crown width and fourth for d.b.h. and height in Guangxi province, China at 2.5 years after planting (ZHENG et al., 1994). In Zheng's study, the worst provenance for d.b.h. and height was Kemps Bay following by Roker Cay and Stained Cay. In general terms, the results suggested that provenances from Abaco Island are the bests.
The best growing provenance exceeded the least growing provenance by 7, 8 and $18 \%$ for d.b.h., height, and volume, respectively. Differences in traits growth were greater among families than among provenances. The best growing family exceeded the second best growing family by 2,3 , and $4 \%$ for d.b.h., height, and volume, and the least growing family by 27,21 and $50 \%$, respectively (data not shown), showing the potential of provenance-progeny test of $P$. caribaea var. bahamensis for selection.

Comparing the mean annual growth rate estimated over all provenance (d.b.h. $=1.52 \mathrm{~cm}$, height $=1.03 \mathrm{~m}$, volume $=0.0207 \mathrm{~m}^{3}$ ) with the measured in $P$. caribaea var. bahamensis plot (d.b.h. $=1.42 \mathrm{~cm}$, height $=1.15 \mathrm{~m}$, volume $=0.026 \mathrm{~m}^{3}$ ), we can conclude that the studied provenances has a good performance for d.b.h., but not 
for height and volume. But, based on a comparison of the annual growth rate of $P$. caribaea var. bahamensis provenances with the observed by FREITAS et al. (2005) in the same species at 22 years old for average growth of the best of the 22 open-pollinated families (d.b.h. $=1.29$ $\mathrm{cm}$, height $=1.05 \mathrm{~m}$ ) planting in Bebedouro, São Paulo State, Brazil, is possible to conclude that the species showed a good growth rate at this site. Still, comparing the annual growth rate with observed in a P. elliottii var. elliottii plot established in a commercial stand (d.b.h. = $1.34 \mathrm{~cm}$, height $=0.85 \mathrm{~m}$; volume $0.0230 \mathrm{~m}^{3}$ ) at the same site, we observed the superiority of the tested species for d.b.h. and height growth.

\section{Genetic parameters}

Genetic correlations $\left(r_{\sigma}\right)$ on growth traits were substantially high and statistically significant $\left(r_{g(\text { d.b.h. } \text { height })}=0.58, \quad P<0.05 ; \quad r_{g(\text { d.b.h.-volume })}=0.98\right.$, $P<0.01) ; r_{g(\text { height-volume })}=0.72, P<0.01$ ) indicating that gains could be made through indirect selection for one trait based on direct selection for another. These genetic correlations are very similar to those reported by MISsIO et al. (2004) studying 119 families of the same species at 13 years old in Ilha Solteira, São Paulo State, Brazil. The authors observed genetic correlation of 0.62 among d.b.h. and height, 0.97 among d.b.h. and volume, and 0.71 among height and volume.

The thinning based on resin yield may have biased the estimative of genetic parameters if resin yield and growth traits were correlated and if a different number of trees were selected per subplot or family, benefiting trees in some subplots from lower competition for growth, hence influencing the results. However, correlation between resin yield and growth traits seems to be low. Studies conducted in Brazil with $P$. elliottii var. elliottii suggest a low and not significant genetic correlation between resin yield and d.b.h. and height $(<0.5$, Gurgel Garrido and Kageyama, 1993; Romanelli and SEBBENN, 2004). Also, the thinning was homogeneous across the subplots with two trees being removed from each sub-plot. Thus, we believe that selection for resin yield did not have an effect in our estimates of variance components and genetic parameters.

The coefficient of genetic variation among families was higher for volume, following by d.b.h. and height (Table 3). In comparison to previous results at 6 years of age (GURGEL GARRIDO et al., 1997), the genetic variation increase for d.b.h. $\left(C V_{g}=3.85 \%\right)$ and decrease for height $\left(C V_{g}=12.35 \%\right)$, following the same pattern observed for variances among families (Figure 1). The genetic variation was also smaller than detected by Missio et al. (2004) at age 13 (d.b.h., $C V_{g}=5.57 \%$; height, $C V_{g}=2.0 \%$, volume, $\left.C V_{g}=14.05 \%\right)$, but higher than the one detected at age five (d.b.h., $C V_{g}=1.86 \%$; height, $C V_{g}=1.06 \%$, volume, $C V_{g}=4.35 \%$, SEBBENN et al., 1994) and 22 (d.b.h., $C V_{g}=2.27 \%$; height, $C V_{g}=1.9 \%$, volume, $C V_{g}=6.8 \%$, FREITAS et al., 2004) in 22 families growing in Bebedouro, São Paulo State. Although, there are some differences in the estimates at different age and populations, all results show the same pattern, with high genetic variation for volume, followed by d.b.h. and height, indicating that more genetic progress can be expected from selection for volume and d.b.h. than height.

The estimates of heritability (Table 3 ) at individual $\left(h_{i}^{2}\right)$, within families $\left(h_{w}^{2}\right)$, and among family levels $\left(h_{f}^{2}\right)$ were higher for d.b.h. and volume than height, in accordance with the coefficient of genetic variation, indicating a higher genetic control of these traits. The corresponding family mean heritability was substantial and suggests a high potential for selection among families. The higher values of heritabilities for d.b.h. and the high genetic correlation of this trait with volume, indicates that d.b.h. is the best trait to use in selection.

\section{Acknowledgements}

The authors are grateful to the Oxford Forestry Institute, particularly, for providing the seeds for this trial. The author A.M.S would like to thank the Conselho National of Desenvolvimento Científico e Tecnológico (CNPq) for granting him a scholarship for Achievements in Research. The authors thank MARILYN D. LOVELESS for suggestions to the early version of the manuscript. The authors also thanks for two anonymous referees by important comments, suggesting and constructive criticism that improved the manuscript.

\section{References}

BARRetT, W. H. G. and L. Golfari (1962): Description de los nuevas variabilidade del "Pino del caribben". Caribean Forester 23: 59-71.

FALCONER, D. S. and T. F. C. MACKAY (1996): Introduction to quantitative genetics, $4^{\text {th }}$ edn. Longman, Harlow, England. 464pp.

Freitas, M. L. M., A. M. Sebbenn, E. Moreas, A. C. S. Zanatto, C. M. R. Sousa and S. L. Lemos (2005): Estimativa de parâmetros genéticos e ganhos na seleção em Pinus caribaea var. bahamensis, aos 22 anos de idade. Rev. do Inst. Flor. 17: 103-111.

GuRgel GarRido, L. M. A. and P. Y. Kageyama (1993): Evolução, com a idade, de parâmetros genéticos de Pinus elliottii var. elliottii Engelm., selecionado para a produção de resina. Rev. do Inst. Flor. 5: 21-37.

Gurgel Garrido, L. M. A., R. C. Romanelli and M. A. O. GARRIDO (1996): Variabilidade genética de produção de resina, DAP e altura em Pinus caribaea Mor. var. bahamensis. Barr. et. Golf. Rev. do Inst. Flor. 8: 89-98.

Gurgel Garrido, L. M. A., M. A. O. Garrido, C. L. S. Pires and M. PAlOMo (1999): Variação genética em progênies e procedências de Pinus caribaea Mor. var. bahamensis. Barr. et. Golf. para a produção de resina e característica de crescimento. Rev. do Inst. Flor. 11: $105-121$.

Matheson, A. C., J. C. Bell and R. D. Barnes (1989): Breeding system and genetic structure in some Central American pine populations. Silvae Genetica 38: 107-113.

Missio, R. F., J. Cambuim, M. L. T. Moraes and R. C. PAUla (2004): Seleção simultânea de caracteres em progênies de Pinus caribaea Morelet var. bahamensis. Scientia Forestalis 66: 161-166.

NAMKOONG, G. (1979): Introduction to quantitative genetics in forestry. Technical Bulletin No 1588, Forest Service, Washington, D.C.

RITLAND, K. (1989): Correlated matings in the partial selfer Mimulus guttatus. Evolution 43: 848-859. 
Romanelli, R. C. and A. M. Sebbenn (2004): Parâmetros genéticos e ganhos na seleção para produção de resina em Pinus elliottii var. elliottii, no Sul do Estado de São Paulo. Rev. do Inst. Flor. 16: 11-23.

Sebbenn, A. M., C. L. S. Pires, L. Stork and A. Custodio FilHo (1994): Variação genética em progênies de meiosirmãos de Pinus caribaea Mor. var. bahamensis Bar. et. Gol. na Região de Bebedouro-SP. Rev. do Inst. Flor. 6: 63-73.

S.A.S. (1989): Institute Inc. SAS Procedures Guide. Version 8 (TSMO). SAS Institute Inc. Cary, N.C., 27513, USA.

WRIGHT, J. W. (1978): A simplified design for combined provenance and progeny testing. Silvae Genetica 27: 68-70.
ZhenG, Y. O. and R. EnNos (1997): Changes in mating system of populations of Pinus caribaea Morelet var. caribaea under domestications. Forest Genetics 4: 209-215.

ZHENG, Y. O. and R. ENNOS (1999): Genetic variability and structure of natural and domesticated populations of caribaean pine (Pinus caribaea Morelet). Theor. Appl. Genet. 98: 765-771.

Zheng, Y. O., R. EnNos and H. R. WANG (1994): Provenance variation and genetic parameters in a trial of Pinus caribaea Morelet var. bahamensis and Golf. Forest Genetics 1: 165-174.

\title{
Short Note: Root Restriction Hindered Early Allometric Differentiation Between Seedlings of Two Provenances of Canary Island Pine
}

\author{
By J. Climent ${ }^{1),}{ }^{*}$, J. Alonso ${ }^{2)}$ and L. GiL ${ }^{2)}$
}

(Received $5^{\text {th }}$ December 2006)

\begin{abstract}
Based on the optimal partitioning theory, the comparative assessment of seedling allometry is a common task in retrospective genetic tests and early testing of forest reproductive material. Our hypothesis was that root restriction imposed by the container might hinder or rule out genetic differences in biomass allocation. We grew seedlings of two contrasted provenances of Canary Islands pine in mini-rhizotrons, 60 and $90 \mathrm{~cm}$ deep, and alternatively in standard bottom-open $200 \mathrm{cc}$ forest containers. In the mini-rhizotrons, plants from the drier provenance allocated more biomass to roots, especially to the tap root and invested less in needles, both in a biomass and leaf area basis, and this morphological divergence increased between two harvests, undertaken at 57 and 115 days after planting. By contrast, confirming our hypothesis, at the 115 days harvest, the plants grown in standard containers did not exhibited significant differences between provenances for Leaf Mass Fraction, Root Mass Fraction and Leaf Area Ratio. We conclude that the physical constraint for root development imposed by small containers increases the probability of dismissing the genetic effect in biomass alloca-

1) Unidad de Genética Forestal - INIA. Ctra. de la Coruña Km 7.5, 28040 Madrid. España.

2) Unidad Docente de Anatomía, Fisiología y Genética Forestales, ETSIM, UPM, Ciudad Universitaria s/n, 28040 Madrid. España.

*) Corresponding author: J. Climent, Unidad de Genética Forestal, Instituto Nacional de Investigación y Tecnología Agraria y Alimentaria (INIA) , Ctra. de la Coruña $\mathrm{Km} \mathrm{7.5,} \mathrm{28040-}$ Madrid (ESP). Tel.: +34(91) 3476862 . Fax.: +34(91) 3476767. E-mail: climent@inia.es.
\end{abstract}

tion when assessing forest reproductive materials at the short term, even when the whole plant growth (total dry weight) might be unaffected.

Key words: Mini-rhizotrons, root architecture, container, biomass allocation, ontogeny.

\section{Introduction}

Seedling allometry and root architecture are widely recognised as traits of adaptive and evolutionary significance in plants (NIKLAS and ENQUIST, 2002; NIKLAS, 2004; KeRKHOFF and EnqUisT, 2006) and closely related to plant field performance (WANG and SмIтH, 2004). Root conformation is a key aspect in plant adaptation to different and variable soil and climate, allowing the capture of water and nutrients at different levels in the soil; in fact rooting depth has been postulated to correspond to adaptive strategies across biomes at the global level (GLIMSKAR, 2000; GUERRERO-CAMPO and FitTer, 2001).

In forest species, determining seedling allometry and root architecture are common tasks in retrospective genetic tests and early testing of reproductive material (planting stock quality) (APHALO and RIKALA, 2003; BEAULIEU et al., 2004). However, the available information on whole plant allometry and root traits in forest species is insufficient (DANJON et al., 1999; PAZ, 2003; DANJON et al., 2005), especially considering intra-specific variation (RETZLAFF et al., 2001). On the other hand, the effect of container size and the subsequent mechanical restriction to root growth has been widely studied in a plethora of forest trees and horticultural plants (see for 